\title{
Allelopathic potential and chemical characterisation of 'flor- de-papagaio' bark (Norantea guianensis)
}

Ademir Kleber Morbeck-de-Oliveira, Rosemary Matias, Kelly Cristina Lacerda-Pereira, Elvia Silvia Rizzi \& Jéssica de Araújo Izaías-Muller

Programa de Pós-Graduação em Meio Ambiente e Desenvolvimento Regional, Universidade Anhanguera-Uniderp, Rua Alexandre Herculano, 1400, Campo Grande, Mato Grosso do Sul, Brazil

\section{Correspondence}

A.K. Morbeck-de-Oliveira

E-mail: akmorbeckoliveira@gmail.com

Received: 12 June 2020

Accepted: 24 February 2021

Published on-line: 21 March 2021

\section{Resumen}

Potencial alelopático de la corteza de la especie de 'flor de loro' (Norantea guianensis)

El objetivo fue llevar a cabo la prospección fitoquímica de la cáscara de Norantea guianensis y evaluar su potencial alelopático en la germinación de semillas y el crecimiento inicial de plántulas de lechuga y tomate, utilizando extractos acuosos y etanólicos. Se identificaron compuestos fenólicos y sus derivados, flavonoides y taninos, así como cumarinas, antraquinonas, alcaloides y saponinas. Se produjo interferencia negativa en la germinación y el vigor, especialmente en las semillas de tomate, y los extractos afectaron negativamente el desarrollo de las plántulas. La especie $N$. guianensis tiene la capacidad de interferir en el desarrollo de otras plantas y por esta razón, su uso debe evaluarse cuidadosamente.

Palabras clave: Alelopatía; Aleloquímicos; Metabolitos secundarios.

\begin{abstract}
The purpose of thisstudy was to carry out phytochemical prospecting of Norantea guianensis bark and to evaluate its allelopathic potential in seed germination and the initial growth of lettuce and tomato seedlings using aqueous and ethanolic extracts. We identified phenolic compounds and derivatives, flavonoids, and tannins, as well as coumarins, anthraquinones, alkaloids, and saponins. Negative interference was observed in germination and vigour tests, mainly in tomato seeds, with extracts negatively affecting seedling development. The species $N$. guianensis has the ability to interfere in the development of other plants, and for this reason, its use should be carefully evaluated.
\end{abstract}

Key words: Allelopathy; Allelochemicals; Secondary metabolites. 


\section{Introduction}

The species Norantea guianensis Aubl., Marcgraviaceae, popularly known as 'flor-de-papagaio' (Figure 1), is a tree or hemiepiphyte found in rupestrian fields and savannahs of the Cerrado and Amazon biome, in addition to other vegetation formations. Because it is easy to propagate, in addition to having lush flowers, it is suitable for landscape projects (Cunha et al. 2008).

In landscape projects, there is concern with the use of native species as ornamental plants taking into account the functionality of plant compositions, care with the bioclimatic conditions of each location, and respect for the geomorphological conditions found in nature in order to provide good plant development and to create comfortable microclimates for the user (Heiden et al. 2006). However, there is no concern on the part of the landscaping companies with the predominance of one species over the other in the same environment; although, Cardoso (2013) highlights the importance of studying species of Brazilian auctotone flora, used as ornamental plants, which have the ability to interfere with the establishment and/ or development of other species.

The success of this ornamental species in landscape projects depends, among other factors, on its allelopathic effect among other species in the same environment. Certain species have chemical substances that, when released into the environment, will positively or negatively interfere in the development of other plants, a process called allelopathy, which has the function of reducing or eliminating the competition for resources through chemical substances; although, compounds that are toxic for one species may not be for others (Rice 1984, Fujii \& Hiradate 2007).

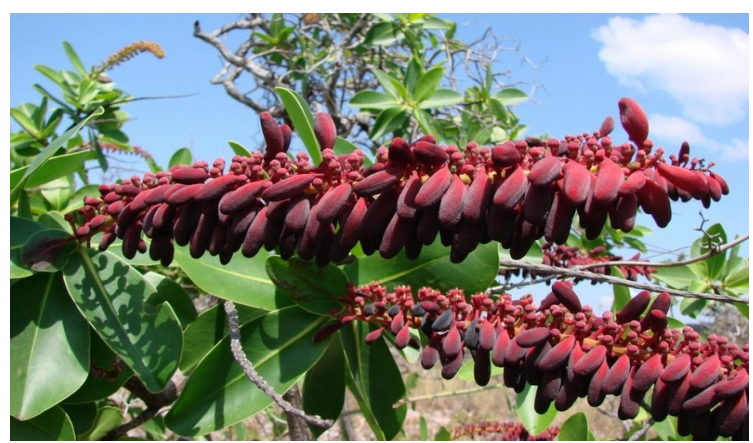

Figura 1. Imagen de hojas y flores de Norantea guianensis. Fotografía: João Medeiros.

Figure 1. Image of leaves and flowers of Norantea guianensis. Photography: João Medeiros.
These chemical compounds, when released, such as by leaching from the aerial part (e.g. leaves) (Macias et al. 2003, Fujii \& Hiradate 2007), can negatively interfere with the assimilation of nutrients, growth, photosynthesis, and respiration. For example, tomato (Solanum lycopersicum L.) and lettuce (Lactuca sativa L.) (Macias et al. 2003, Ferreira 2004) by coumarins and alkaloids. To evaluate the allelopathic potential of a plant, the most common method There is a great diversity of allelochemicals that interfere in the germination and growth processes of plants, among which can be mentioned the phenolic compounds (flavonoids and tannins), terpenoids (saponins and triterpenes), heterosides is through studying the effects of the extracts of the species on seeds and/or seedlings of high-quality cultivated plants

There are no reports on the species $N$. guianensis and its behaviour when grown in gardens, in addition to an absence of studies citing tests for allelopathic activity of its bark, its chemical characteristics, and the class of secondary metabolites present. In this way, the main objective of this work was to test the hypothesis that this vegetal species has the capacity to negatively interfere with the growth of other vegetal species through allelopathy.

\section{Materials and methods}

\section{Sample collection}

The biological material (bark) of $N$. guianensis was collected manually in March 2017 in the morning with a machete from 10 matrices located in forests in the Taboco region, Corguinho munic-

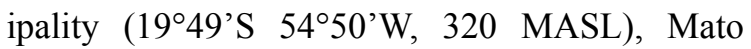
Grosso do Sul, Brazil. The collected bark was stored in sterile polyethylene bags and taken to the Research Laboratory, Campo Grande, Mato Grosso do Sul.

\section{Preparation of extracts}

The bark was fragmented with pruning shears, dried in an oven $\left( \pm 27^{\circ} \mathrm{C}\right)$, and crushed in a mill (with 3 knives; 1,725 rpm; 20 mesh mesh). The material was stored in a glass bottle, sealed, labelled, and kept in the refrigerator until use. Aqueous ( $40 \mathrm{~g}$ of powder for $200 \mathrm{~mL}^{-1}$ of distilled water) and ethanolic ( $40 \mathrm{~g}$ of powder for $200 \mathrm{~mL}^{-1}$ of ethanol - absolute ethyl alcohol Merck ${ }^{\circledR}$ with 
99.9\% purity index) extracts were prepared at a $20 \%$ concentration (crude extract) following the methodology described by Oliveira et al. (2011) and used for phytochemical analysis and bioassays. The crude extract $(20 \%)$ was diluted by adding distilled water to concentrations $2.5,5,10$, 15 , and $20 \%$.

\section{Phytochemical analysis}

The collected plant material was dried in a circulating air oven at $40^{\circ} \mathrm{C}$ and finely ground in a wiley mill. Secondary metabolites were extracted from the powder $(500 \mathrm{~g})$ in an ultrasonic bath for 60 minutes. Phytochemical prospection was done through characterisation reactions to determine the class of secondary metabolites. All analyses were performed in triplicate, following an adapted methodology based on work by Matos (2009) and Simões et al. (2017).

For the assays, alterations in colour or precipitation were compared to the control following the method described by Fontoura et al. (2015). The observed intensities were classified into strongly positive $(+++=100 \%)$, moderately positive $(++=$ $50 \%)$, weakly positive $(+=25 \%)$, and partially positive $( \pm=10 \%)$. A haze or partially changed colour and the absence of colour or precipitation were considered negative. The intensity of the colour or precipitation indicated an increased concentration of each class of secondary metabolite.

Aqueous and ethanolic extracts in concentrations of $2.5,5,10,15$, and $20 \%$ were used to quantify the total phenols ( $\mathrm{mg}$ of gallic acid equivalents per $\mathrm{g}$ of extract - $\mathrm{mg} \mathrm{EAG} / \mathrm{g}^{-1}$ ), determined by the Folin-Ciocalteu method, with gallic acid (10 to $350 \mathrm{mg} \mathrm{mL}^{-1}$ ) as the standard ( $\mathrm{y}=$ $\left.0.02 x+0.042 ; r^{2}=0.9999\right)$ (Sousa et al. 2007). The total flavonoids content (equivalent $\mathrm{mg}$ of quercetin per $\mathrm{g}$ of extract $-\mathrm{mg} \mathrm{EQ} / \mathrm{g}^{-1}$ ) was evaluated by the aluminium chloride method and as standard, quercetin ( 6 to $20 \mu \mathrm{g} \mathrm{mL}^{-1}$ ) to construct the calibration curve $\left(\mathrm{y}=0.042 \mathrm{x}+0.0081 ; \mathrm{r}^{2}=\right.$ 0.9999) (Peixoto-Sobrinho et al. 2008). The extracts were also subjected to analyses of $\mathrm{pH}(\mathrm{pH}$ DM-20, Digimed) and the average $\mathrm{pH}$ of the extracts was $4.2 \pm 0.2$ (aqueous) and 5.6 \pm 0.4 (ethanolic). The osmotic potential was between - 0.042 Mpa (aqueous) and - 0.003 Mpa (ethanolic), determined using a formula proposed by Ayers \& Westcot (1991). The results found for both parameters are considered adequate for the germination and seedling formation of the target species (Rice 1984, Pattnaik \& Misra 1987, Ferreira \& Aqüila 2000, Gatti et al. 2004).

\section{Germination in a germination chamber}

Five mililitres of the aqueous and ethanolic extracts, with concentrations of $2.5,5,10,15$, and $20 \%$ were placed on two sheets of germitest paper in Petri dishes (7 cm in diameter) sealed with film paper. Two controls were used: distilled water and ethanol $(99.9 \%)$. In the control with ethanol, $5 \mathrm{ml}$ of ethanol were placed on the Petri dishes and after their evaporation, the Petri dishes was moistened with $5 \mathrm{ml}$ of distilled water. Four replicates were used with 25 lettuce seeds, cultivar "Maravilha Quatro Estações," and 25 tomato seeds, cultivar "Santa Clara." Observation of the seeds was done every 24 hours for 7 days, and seeds were considered germinated when there was a 2 $\mathrm{mm}$ protrusion of the primary root (morphological criterion of germination).

\section{Growth in a germination chamber}

Ten milliltres of the extracts were used, with concentrations of $2.5,5,10,15$, and $20 \%$, and placed on two sheets of germitest paper in transparent plastic boxes $(11 \times 11 \times 3.5 \mathrm{~cm})$ sealed with film paper. Two controls were used: distilled water and ethanol (99.9\%). In the control with ethanol, 10 $\mathrm{ml}$ of ethanol were placed on the plate and after their evaporation, the plate was moistened with 10 $\mathrm{ml}$ of distilled water. Each treatment consisted of 4 replications with 10 pre-germinated seeds with $\pm 2 \mathrm{~mm}$ of primary root, and the evaluation was made after 10 days (no further moistening of the plates after sowing). The bioassays were maintained in germination chambers at a constant temperature of $20^{\circ} \mathrm{C}$ (lettuce) and $25^{\circ} \mathrm{C}$ (tomato) with a 12-hour photoperiod of white light (20 W fluorescent lamps). Measurement of the primary root was made from the seedling lap to the meristematic apex of the root system ( $\mathrm{mm}$ ) and the aerial part (mm), which is from the plant lap to the apical meristem apex, using a digital calliper.

\section{Germination in a greenhouse}

Emergency tests were performed using seeds from the 2 target species ( 4 replicates with 25 seeds) in expanded polystyrene (styrofoam) trays with 128 cells. Crushed bark was added to the substrate vermiculite at concentrations of 5\% (950 g vermiculite $+50 \mathrm{~g}$ bark powder), 10\% (900 g+100 g ), $20 \%(800 \mathrm{~g}+200 \mathrm{~g})$, and control (vermiculite 
only). The substrates were homogenised, moistened with distilled water, and placed in the trays. One seed of the target species was placed per cell and covered with a thin layer of substrate to evaluate germination and emergence speed index.

\section{Growth in a greenhouse}

The seedlings obtained in a greenhouse through 4 replications with 10 pre-germinated seeds with \pm 2 $\mathrm{mm}$ of primary root length, which were placed in the cells with the substrate in the same proportions as the germination experiment, were evaluated. Seedling growth was measured after 10 days of experimentation. Measurement of the primary root was made from the seedling lap to the meristemic apex of the root system $(\mathrm{mm})$ and the aerial part (mm), which is from the plant lap to the apical meristem apex, using a digital calliper.

\section{Evaluated parameters, experimental design, and statistical treatment}

The germination and vigour percentage, indirectly measured by the mean germination time (MGT) in days, was evaluated, quantifying germination from a kinetic point of view (Labouriau \& Agudo 1987) and the germination speed index (GSI) in addition to the emergency speed index (ESI) (Maguire 1962).

The experimental design was completely randomised, with four replications per treatment. The phytochemical evaluation was carried out with three repetitions for each concentration and the calculation of the means, accompanied by the standard deviation. The data of the evaluated characteristics were subjected to ANOVA, and when there was significance the means were compared using the Tukey test, with $5 \%$ probability, performed using the statistical program Assistat. There was the need for data transformation according to the Shapiro-Wilk tests for normality of ANOVA and Levene residues for homogeneity between variances, with untransformed data being presented, for easy understanding of the results.

\section{Results}

The phenolic compounds, tannins, coumarins, and alkaloids had a moderately positive intensity in both extracts, and the anthraquinones had a moderately positive intensity in the aqueous extract and a strong intensity in the ethanolic extract.
Flavonoids and saponins had low intensity in both extracts (Table 1).

Regarding the content of phenolic and flavonoid compounds, the values of the aqueous and ethanolic extracts were statistically different. The highest values occurred in extracts $20 \%$ and the lowest in extracts $2.5 \%$. The reduction in the concentration of phenolic compounds reached $23.2 \%$ and for flavonoids reached $73.2 \%$. The aqueous extract was more efficient in extracting the compounds (Table 2).

The dilution process of the crude extract $(20 \%)$ resulted in a reduction in the concentration of phenolic compounds and total flavonoids. The reduction was greater in the aqueous extract (22.8\% for phenolic compounds and $72 \%$ for flavonoids) compared to the ethanolic extracts (12.9\% for phenolic compounds and $50.7 \%$ for flavonoids).

\section{Germination and growth}

In the germination chamber, the germination of lettuce seeds was negatively affected in only the

\begin{tabular}{lll}
\hline \multicolumn{1}{c}{ Secondary metabolites } & aqueous & ethanolic \\
\hline Phenolic compounds & ++ & ++ \\
Tannins & ++ & ++ \\
Flavonoids & + & + \\
Coumarins & ++ & ++ \\
Anthraquinones & ++ & +++ \\
Alkaloids & ++ & ++ \\
Saponins & + & + \\
\hline
\end{tabular}

Tabla 1. Metabolitos secundarios de extracto acuoso y etanólico, corteza de Norantea guianensis. Fuertemente positivo $(+++=$ $100 \%)$, moderadamente positivo $(++=50 \%)$ e débilmente positivo $(+=25 \%)$.

Table 1. Secondary metabolites of aqueous and ethanolic extracts of Norantea guianensis. Strongly positive $(+++=100 \%)$, moderately positive $(++=50 \%)$, and weakly positive $(+=25 \%)$.

\begin{tabular}{ccccc}
\hline & \multicolumn{2}{c}{ Phenolic compounds } & \multicolumn{2}{c}{ Flavonoids } \\
\hline$\%$ & aqueous & $\begin{array}{c}\text { ethanolic } \\
\text { extract }\end{array}$ & aqueous & ethanolic \\
& extract & extract & extract \\
\hline $\mathbf{2 0}$ & $56.1 \pm 0.2 \mathrm{aA}$ & $48.9 \pm 0.3 \mathrm{aB}$ & $38.6 \pm 0.5 \mathrm{aA}$ & $21.3 \pm 0.3 \mathrm{aB}$ \\
$\mathbf{1 5}$ & $51.8 \pm 0.3 \mathrm{bA}$ & $46.8 \pm 0.1 \mathrm{bB}$ & $27.6 \pm 0.5 \mathrm{bA}$ & $18.1 \pm 0.1 \mathrm{bB}$ \\
$\mathbf{1 0}$ & $48.2 \pm 0.1 \mathrm{cA}$ & $46.4 \pm 0.9 \mathrm{bB}$ & $21.2 \pm 0.4 \mathrm{cA}$ & $16.1 \pm 0.2 \mathrm{cB}$ \\
$\mathbf{5}$ & $45.1 \pm 0.2 \mathrm{dA}$ & $44.1 \pm 0.4 \mathrm{cB}$ & $14.5 \pm 0.1 \mathrm{dA}$ & $12.4 \pm 0.1 \mathrm{~dB}$ \\
$\mathbf{2 . 5}$ & $43.3 \pm 0.5 \mathrm{eA}$ & $42.6 \pm 0.2 \mathrm{dA}$ & $10.8 \pm 0.2 \mathrm{eA}$ & $10.5 \pm 0.2 \mathrm{eA}$ \\
\hline
\end{tabular}

Tabla 2. Contenido de compuestos fenólicos (mg EAG/g-1) y flavonoides totales (mg EQ/g-1) de los extractos acuosos y etanólicos de la corteza de Norantea guianensis en diferentes concentraciones. *Los promedios seguidos de la misma letra en la columna no difieren estadísticamente, prueba de Tukey $(\mathrm{p}<0.05)$. Table 2. Content of phenolic compounds (mg EAG/g-1) and total flavonoids (mg EQ/g-1), aqueous and ethanolic extracts of Norantea guianensis. *Means followed by the same lowercase letters in a column and capital letters on the lines do not differ significantly by the Tukey test $(\mathrm{p}<0.05)$. 
$20 \%$ aqueous extract. The germination of tomato seeds suffered the effects of metabolites from the $5 \%$ aqueous and ethanolic extract (Table 3). Regarding the vigour of lettuce seeds, measured indirectly by GSI and MGT (Table 3 ), the aqueous extracts interfered negatively from the concentration of 5\%; the ethanolic extracts from the concentration of $15 \%$. Tomato seeds were affected by the concentration of $5 \%$ in both extracts.

The results indicated a greater effect of the $20 \%$ extracts on the germination of tomato seeds, reducing germination by $91 \%$ (ethanol extract) and $78 \%$ (aqueous extract). There is no reduction in the germination of lettuce seeds for any of the concentrations of the ethanolic extracts tested and in the case of the aqueous extracts only a $12 \%$ reduction in germination is observed in the presence of $20 \%$ aqueous extracts (Table 3 ).

At a concentration of $20 \%$, the GSI of tomato seeds was also more affected, with a reduction between $87 \%$ (aqueous) and 92\% (ethanolic), while lettuce was between $16 \%$ (ethanolic) and $46 \%$ (aqueous). Regarding the MGT, there was an increase in germination time of $108 \%$ (ethanol extract) and $21 \%$ (aqueous extract) for tomato seeds and of $31 \%$ (ethanol) and $70 \%$ (aqueous) for lettuce seeds (Table 3).

The seedling development results in a germination chamber (Table 4) demonstrated that all extracts had a negative influence on the develop-

\begin{tabular}{|c|c|c|c|c|c|c|}
\hline & \multicolumn{2}{|c|}{ Germination } & \multicolumn{2}{|c|}{ GSI } & \multicolumn{2}{|c|}{ MGT } \\
\hline & ethanol. & aqueo. & ethanol. & aqueo. & ethanol. & aqueo. \\
\hline Lettuce & 99 a & 98 a & $24 \mathrm{a}$ & $24.2 \mathrm{a}$ & $0.26 \mathrm{a}$ & $0.27 \mathrm{a}$ \\
\hline $\begin{array}{c}2.5 \% \\
5 \% \\
10 \% \\
15 \% \\
20 \%\end{array}$ & $\begin{array}{l}99 \text { a } \\
99 \text { a } \\
99 \text { a } \\
98 \text { a } \\
98 \text { a }\end{array}$ & $\begin{array}{c}98 \mathrm{a} \\
100 \mathrm{a} \\
96 \mathrm{a} \\
96 \mathrm{a} \\
88 \mathrm{~b}\end{array}$ & $\begin{array}{c}24 \mathrm{a} \\
24 \mathrm{a} \\
23.4 \mathrm{ab} \\
21.3 \mathrm{~b} \\
20.1 \mathrm{~b}\end{array}$ & $\begin{array}{c}22.7 a b \\
21.9 b \\
20.3 b \\
16.6 c \\
13.1 d\end{array}$ & $\begin{array}{l}0.26 \mathrm{a} \\
0.26 \mathrm{a} \\
0.28 \mathrm{a} \\
0.32 \mathrm{~b} \\
0.34 \mathrm{~b}\end{array}$ & $\begin{array}{c}0.28 \mathrm{a} \\
0.33 \mathrm{~b} \\
0.35 \mathrm{bc} \\
0.39 \mathrm{c} \\
0.46 \mathrm{~d}\end{array}$ \\
\hline $\begin{array}{l}\text { Tomato } \\
\text { control }\end{array}$ & 95 a & $94 \mathrm{a}$ & $8.6 \mathrm{a}$ & $10.0 \mathrm{a}$ & $0.77 \mathrm{a}$ & $0.82 \mathrm{a}$ \\
\hline $\begin{array}{c}2.5 \% \\
5 \% \\
10 \% \\
15 \% \\
20 \%\end{array}$ & $\begin{array}{c}91 \mathrm{a} \\
76 \mathrm{~b} \\
24 \mathrm{c} \\
13 \mathrm{~d} \\
9 \mathrm{~d}\end{array}$ & $\begin{array}{l}94 \mathrm{a} \\
84 \mathrm{~b} \\
65 \mathrm{c} \\
35 \mathrm{~d} \\
22 \mathrm{e}\end{array}$ & $\begin{array}{l}8.9 \mathrm{a} \\
7.1 \mathrm{~b} \\
3.1 \mathrm{c} \\
1.3 \mathrm{~d} \\
0.7 \mathrm{e}\end{array}$ & $\begin{array}{l}8.7 \mathrm{a} \\
6.0 \mathrm{~b} \\
4.4 \mathrm{c} \\
2.9 \mathrm{~d} \\
1.3 \mathrm{e}\end{array}$ & $\begin{array}{l}0.91 \mathrm{a} \\
1.4 \mathrm{~b} \\
1.4 \mathrm{~b} \\
1.7 \mathrm{~b} \\
1.6 \mathrm{~b}\end{array}$ & $\begin{array}{c}0.80 \mathrm{a} \\
0.91 \mathrm{~b} \\
0.99 \mathrm{c} \\
1.0 \mathrm{c} \\
0.99 \mathrm{c}\end{array}$ \\
\hline
\end{tabular}

Tabla 3. Germinación (\%), índice de velocidad de germinación (GSI) y tiempo medio de germinación (MGT) de semillas de lechuga y tomate en extracto acuoso y etanólico, corteza de Norantea guianensis, cámara de germinación. *Los promedios seguidos de la misma letra en la columna no difieren estadísticamente, prueba de Tukey $(\mathrm{p}<0.05)$.

Table 3. Germination (\%), germination speed index (GSI), and mean germination time (MGT) of lettuce and tomato seeds in aqueous and ethanolic extracts of Norantea guianensis in germination chamber. *Averages followed by the same letter in the column do not differ significantly by the Tukey test $(\mathrm{p}<0.05)$. ment of roots and shoots, starting from concentrations of 5\% in both extracts and in both types of seeds, the effect being more pronounced as the concentration of said extracts increases. In the greenhouse, there was also a significant reduction in seedling growth. The ethanolic and aqueous extracts, from the concentration of $2.5 \%$, reduced the growth of the root system and the aerial part, lettuce and tomato seedlings, with the effect being more pronounced as the concentration of said extracts increases and the ethanolic extract leading to the death of tomato seedlings at a concentration of $20 \%$. The results obtained in the greenhouse also demonstrated that the germination and emergence speed index of both target species were negatively affected at the $5 \%$ concentration, with seeds germinating less and taking longer to emerge (Table 5).

\section{Discussion}

In relation to phytochemical studies with the species N. guianensis, Saleh \& Towers (1974) identified the presence of glyco-flavonoids in flowers, while Dressler (2004) indicated that terpenes, tannins, saponins, alkaloids, and phenolic compounds are common in this family. The analyses indicated that among the metabolites present in the aqueous and ethanolic extracts, phenolic compounds appear with medium intensity, which correspond to a group of allelochemicals that have

\begin{tabular}{ccccc}
\hline & \multicolumn{2}{c}{ Roots $(\mathbf{m m})$} & \multicolumn{2}{c}{ Steams $(\mathbf{m m})$} \\
\cline { 2 - 5 } & ethanolic & aqueous & ethanolic & aqueous \\
\hline Lettuce & $13.1 \mathrm{a}$ & $16.6 \mathrm{a}$ & $12.4 \mathrm{a}$ & $12.9 \mathrm{a}$ \\
control & & & & \\
$\mathbf{2 . 5 \%}$ & $5.4 \mathrm{~b}$ & $12.7 \mathrm{~b}$ & $10.1 \mathrm{~b}$ & $11.6 \mathrm{~b}$ \\
$\mathbf{5 \%}$ & $2.9 \mathrm{c}$ & $6.6 \mathrm{c}$ & $5.7 \mathrm{c}$ & $10.9 \mathrm{~b}$ \\
$\mathbf{1 0 \%}$ & $2.3 \mathrm{c}$ & $4.9 \mathrm{c}$ & $3.6 \mathrm{~d}$ & $8.2 \mathrm{c}$ \\
$\mathbf{1 5 \%}$ & $2.1 \mathrm{c}$ & $3.8 \mathrm{~d}$ & $3.3 \mathrm{~d}$ & $6.3 \mathrm{~d}$ \\
$\mathbf{2 0 \%}$ & $1.4 \mathrm{~d}$ & $2.3 \mathrm{e}$ & $1.1 \mathrm{e}$ & $4.2 \mathrm{e}$ \\
\hline Tomato & $68.4 \mathrm{a}$ & $65.3 \mathrm{a}$ & $33.2 \mathrm{a}$ & $37.7 \mathrm{a}$ \\
control & & & & \\
$\mathbf{2 . 5 \%}$ & $26.5 \mathrm{~b}$ & $31.2 \mathrm{~b}$ & $19.6 \mathrm{~b}$ & $32.1 \mathrm{~b}$ \\
$\mathbf{5 \%}$ & $13.8 \mathrm{c}$ & $24.5 \mathrm{~b}$ & $17.3 \mathrm{~b}$ & $29.5 \mathrm{~b}$ \\
$\mathbf{1 0} \%$ & $7.6 \mathrm{~d}$ & $11.4 \mathrm{c}$ & $9.1 \mathrm{c}$ & $15.4 \mathrm{c}$ \\
$\mathbf{1 5 \%}$ & $0 \mathrm{e}$ & $6.6 \mathrm{~d}$ & $1.9 \mathrm{~d}$ & $17.1 \mathrm{c}$ \\
$\mathbf{2 0} \%$ & $0 \mathrm{e}$ & $1.3 \mathrm{e}$ & $0 \mathrm{e}$ & $16.3 \mathrm{c}$ \\
\hline
\end{tabular}

Tabla 4. Longitud promedio $(\mathrm{mm})$ de raíces y tallos, plántulas de lechuga y tomate, extracto acuoso y etanólico, corteza de Norantea guianensis, en cámara de germinación. *Los promedios seguidos de la misma letra en la columna no difieren estadísticamente, prueba de Tukey $(\mathrm{p}<0.05)$.

Table 4. Average length $(\mathrm{mm})$ of the roots and stems of lettuce and tomato seedlings in aqueous and ethanolic extract of Norantea guianensis in germination chamber. *Averages followed by the same letter in the column do not differ significantly by the Tukey test $(\mathrm{p}<0.05)$. 


\begin{tabular}{ccccccc}
\hline \multirow{2}{*}{$\begin{array}{c}\text { \% Norantea } \\
\text { guianensis } \\
\text { powder in }\end{array}$} & \multicolumn{2}{c}{ Germination } & \multicolumn{2}{c}{ ESI } & \multicolumn{2}{c}{ Seedlings } \\
\cline { 2 - 7 } vermiculite & lettuce & tomato & lettuce & tomato & lettuce & tomato \\
\hline Control & $88 \mathrm{a}$ & $62 \mathrm{a}$ & $13.1 \mathrm{a}$ & $7.8 \mathrm{a}$ & $46.3 \mathrm{a}$ & $91.9 \mathrm{a}$ \\
$\mathbf{5}$ & $66 \mathrm{~b}$ & $37 \mathrm{~b}$ & $8.8 \mathrm{~b}$ & $3.7 \mathrm{~b}$ & $37.7 \mathrm{~b}$ & $83.6 \mathrm{~b}$ \\
$\mathbf{1 0}$ & $70 \mathrm{~b}$ & $39 \mathrm{~b}$ & $9.3 \mathrm{~b}$ & $3.8 \mathrm{~b}$ & $36.7 \mathrm{~b}$ & $79.7 \mathrm{~b}$ \\
$\mathbf{2 0}$ & $42 \mathrm{c}$ & $41 \mathrm{~b}$ & $3.9 \mathrm{c}$ & $4.1 \mathrm{~b}$ & $37 \mathrm{~b}$ & $73.9 \mathrm{~b}$ \\
\hline
\end{tabular}

Tabla 5. Germinación (\%), índice de velocidad de emergencia (ESI) y tamaño de las plántulas de lechuga y tomate (mm), sustrato de vermiculita con polvo de corteza de Norantea guianensis en diferentes proporciones $(0,5,10$ y $20 \%)$ en vivero.

*Los promedios seguidos de la misma letra en la columna no difieren estadísticamente, prueba de Tukey $(\mathrm{p}<0.05)$.

Table 5. Germination (\%), emergence speed index (ESI), and size of lettuce and tomato seedlings ( $\mathrm{mm}$ ) in substrate with Norantea guianensis powder in different proportions $(0,5,10$ and 20\%) in greenhouse. *Averages followed by the same letter in the column do not differ significantly by the Tukey test $(\mathrm{p}<0.05)$.

a greater allelopathic effect. This class ranges from simple phenols and flavonoids to more complex structures such as tannins. Phenolic compounds are considered potent inhibitors of seed germination (Rice 1984), reducing the formation of lignin, which contributes to the reduction in root elongation, in addition to blocking mitochondrial breathing (Fujii \& Hiradate 2007).

Tannins also occur at medium intensity and can be released under natural conditions since they are water soluble. However, there are few reports of the involvement of tannins in allelopathic activity, with Rice (1984) describing their involvement in the inhibition of the growth hormone gibberellin.

Other derivatives of phenolic compounds are flavonoids, which are found in low intensity. According to Rice (1984), they can inhibit seedling germination and growth, and they are also cited as allelochemicals responsible for causing negative effects, direct and indirect, in the cell division process. Because they have free hydroxyls, they are able to capture electrons and act as catalysts in the photochemical phase of photosynthesis and/or as regulators of ion channels involved in the oxidative phosphorylation of the process of obtaining photosynthetic energy (Piettá \& Simonetti 1999). Their antioxidant activity explains the ability to regulate cell growth and inhibit germination and seedling growth, for example (Macias et al. 1997).

Coumarins, another important allelochemical found in medium intensity, according to Macias et al. (2003) and Willis (2007), act as potent inhibitors in germination and plant growth. For Abenalovi et al. (2006), this effect occurs due to their ability to block mitosis, decreasing water intake and oxygen consumption. Nazemi et al. (2018) describe that coumarin can reduce the amount and activity of Golgi body in lettuce, block mitosis in alfalfa and modify mitochondria structure in onion, demonstrating its strong allelopathic action.

Another class of secondary metabolites with an important role in allelopathic function are anthraquinones (Rice 1984, Simões et al. 2017), with medium and high intensities detected. Murakami et al. (2009), for example, reported allelopathic activity of anthraquinones in the germination and growth of Lemna minor L. Among anthraquinones, sorgoleone, found in sorghum (Sorgum bicolor (L.) Moench), is a potent allelochemical that inhibits the germination and growth of various plants, acting as an inhibitor of photosystem I (Gonzalez et al. 1998). The greater intensity of anthraquinones in the ethanolic extract could justify its more intense effect, in relation to the processes of germination and seedling formation. However, as already mentioned by Fujii \& Hiradate (2007) and Souza Filho et al. (2010), the allelopathic potential can often be related to the joint action of phytochemicals (synergism). On the other hand, Luz et al. (2010), when evaluating the allelopathic activity of pairs of substances and isolated substances of Acacia mangium Willld. on seeds of Mimosa pudica L. and Senna obtusifolia, verified that, separately, the substances promoted effects superior to those effected by the substances in pairs.

Alkaloids, found in medium intensity, can suppress the germination and growth of other species in the environment, as reported by Fujii \& Hiradate (2007) and Willis (2007). Classes like that of alkaloids are related to allelopathic action due to their toxicity, changing the permeability of the membrane of meristem cells, for example, leading to death (Fujii \& Hiradate 2007, Mulac \& Humpf 2011). Alves et al. (2003) report that glycosylated spirosolane alkaloids, such as solamargine and solasonine, can suppress seed germination and growth of other species, even in small concentrations.

The presence of saponins in low intensity, according to Rice (1984) and Macias et al. (2003), also indicates the allelopathic action of the extracts since they present action on the cell membrane, modifying its permeability and interfering 
in the germination and vigour of seeds, leading to damage to cell structures. Saponins are commonly cited as responsible for causing allelopathic effects, as they can be released under natural conditions, as they are water-soluble, reducing the respiratory rate, which inhibits plant germination and growth (Ferreira \& Aqüila 2000, MaraschinSilva \& Áquila 2006), demonstrating its action potential.

Regarding the content of phenolic and flavonoid compounds, a lower concentration of compounds occurs as the dilution increases, which would be expected. The smallest reduction in the concentration of phenolic compounds demonstrates that they are less affected by the dilution process, with the leaching process having little impact on their solubility. Flavonoids, on the other hand, were more affected, which indicates that during the rainy season greater leaching in nature may occur and, consequently, more intense allelopathic action in the environment may occur. The aqueous extract was also more efficient in extracting both metabolites, a factor probably related to the greater polarity of the solvent water.

The action of phenolic compounds and derivatives (flavonoids and tannins), such as allelochemicals, has been described by several researchers. For example, Cipollini et al. (2008) attributed the allelopathic activity of the hydromethanolic extract of Lonicera maackii (Rupr) leaves on the germination of Arabidopsis thaliana (L.) seeds due to the presence of flavonoids, glycoflavonoids, and chlorogenic acid. These compounds can affect different physiological processes of plants, interfering in their development, for example, at the cellular level, influencing lipid metabolism and the biochemical mechanism of respiration, inhibiting glucose transport and cellulose synthesis, which negatively affects the seedling growth (Angelo \& Jorge 2007).

Specifically, studies relating to allelopathy and the determination of phenolic and flavonoid compounds are scarce. Among these, Oliveira et al. (2014) indicated the allelopathic activity of aqueous and ethanolic extracts of Palicourea rigida Kunth leaf on the germination speed of lettuce and seedling development. The action of these compounds has also been reported by Rodrigues et al. (2010), who evaluated the effect of hydromethanolic extract and fractions of Senna alata (L.) leaves in concentrations of 50, 100,
150 , and $200 \mathrm{mg} \mathrm{L}^{-1}$ on seed germination and seedling of three weeds from pastures (Mimosa pudica, Senna obtusifolia, and S. alata), attributing the allelopathic activity to the glycosylated flavonoids present in the fractions. Silva et al. (2013) found that the ethanolic extract and glycoflavonoids isolated from the green leaves of Derris urucu (Killi \& Smith) Macbr. inhibited seed germination and $M$. pudica seedling development. These data show the ability of flavonoids to act in isolation or in complex mixtures to inhibit the tested seeds.

Regarding the germination process, the results showed that the extracts interfered with the germination of both species, with the tomato being more affected by the ethanolic extract. Although both extracts have equal qualitative compositions, the ethanolic extract, which used a solvent with less polarity, was more efficient in the extraction of certain compounds, which may have influenced seed germination and seedling growth.

Regarding the higher sensitivity of tomatoes (Solanaceae), according to Rizzi et al. (2016) this species is more sensitive to secondary metabolites than lettuce (Asteraceae), relating this factor to families with distinct biochemical and physiological processes. Pereira et al. (2018) also found similar results, with tomato seeds being more affected than lettuce when in the presence of Anacardium humille A.St.-Hil extracts. For Rizzi et al. (2016), evaluating how different species behave, in the face of the same allelochemicals, may allow studies aimed at the creation of bio-herbicides designed to combat unwanted species, affecting the others to a minimum.

It could be assumed that free anthraquinones, found in greater intensity in the ethanolic extract, were responsible for greatest action. However, it is not possible to make this statement because, in general, the allelopathic potential of plant extracts must be related to the joint action of phytochemicals (synergism). On the other hand, for certain species, allelochemicals can affect germination differently, being able to alter only the vigour of the seeds and/or the formation of seedlings (Fujii \& Hiradate 2007, Souza Filho et al. 2010), as observed for lettuce.

Interference with germination and/or vigour may also be related to the concentrations used because, depending on this, the results may be different. Authors such as Capobiango et al. (2009) 
have demonstrated that aqueous extracts in concentrations of $10 \%$ and $30 \%$ there were reductions in GSI, while aqueous extracts in concentrations 70, 90, and $100 \%$ did not show results. Evaluating the allelopathic effect of Artemisia annua L. on lettuce, Magiero et al. (2009) found that leaf aqueous extract in the concentration of $25 \%$ led to germination in a longer period of time than the control. Testing the aqueous and ethanolic extracts of Vochysia divergens Pohl, Oliveira et al. (2013) indicated an increase in the MGT of lettuce and tomato seeds from a concentration of $2.5 \%$, demonstrating that the action patterns of the allelochemicals are different depending on the species studied.

Although there was a greater effect on tomato seeds, according to Ferreira (2004), germination may be less affected by allelochemicals. Authors such as Maraschin-Silva \& Áquila (2006), working with Erythroxylum argentinum O.E. Schulz, Luehea divaricata Mart., Myrsine guianensis (Aubl.) Kuntze, and Ocotea puberula (Rich.) Nees (aqueous extracts), indicated that lettuce germination was slightly altered only in the extracts of E. argentinum and L. divaricata, confirming the statement by Ferreira (2004). Carmo et al. (2012), working with species considered to produce allelopathic substances (Pinus elliottii Engelm. and Eucalyptus spp.) in the field, did not find evidence of the allelopathic action of the mentioned species, indicating that the germination process can occur even in the presence of these metabolites.

For extracts of other species, such as Casearia sylvestris $\mathrm{Sw}$, the germination test was only negatively influenced at the highest concentrations of $90 \%$ and $100 \%$, while for Joanesia princeps Vell., the germination inhibition of lettuce seeds occurred from the extract in the concentration of 30\% (Capobiango et al. 2009). Testing fresh leaf extracts of Rheedia brasiliensis (Mart.) Planch. \& Triana in the germination of lettuce seeds, Oliveira et al. (2011) indicated that only at the concentration of $20 \%$ was there a negative effect on germination. On the other hand, Coelho et al. (2011), evaluating extract of juazeiro (Ziziphus joazeiro Mart.) seeds indicated that the effect occurred from the $75 \%$ concentration. Other authors, such as Oliveira et al. (2013), indicated that ethanolic and aqueous extracts of Vochysia divergens, with a concentration of $10 \%$, influ- enced the germination of tomato and lettuce seeds. These results demonstrate different patterns depending on the species tested.

In the greenhouse, the germination and ESI of both target species were negatively affected, indicating the release of allelochemicals through leaching and their interference on the species. Evaluating the results in the germination chamber and greenhouse, it can be observed that in the chamber the effects of the extracts were more deleterious. In environments such as a greenhouse, where environmental conditions such as temperature, light intensity, the presence of ultraviolet and infrared radiation, and the development of microorganisms on the substrate, the effects can be different since these factors can affect the structure of allelochemicals, decreasing their action potential.

According to Almeida et al. (2008), when the presence of variable environmental conditions occurs, the metabolites can undergo oxidative processes, changing their mode of action and, often, reducing their effects. This situation was reported by Pereira et al. (2018), who evaluated Anacardium humile extracts and their action on lettuce, tomato, and fedegoso seeds (Senna obtusifolia (L.) Irwin \& Barneby), with more intense action observed in a germination chamber.

The development of seedlings in a germination chamber indicated that the extracts negatively influenced the development of roots and shoots, with a significant reduction in all treatments. In the greenhouse, there was also a reduction in seedling growth, although on a smaller scale.

It can be observed that although the present compounds have negatively affected the entire seedling, the growth of the roots was more affected. Hagemann et al. (2010) described that the root system is the most sensitive to allelochemicals because, according to Fujii \& Hiradate (2007), its rapid elongation depends on efficient cell division, which can be affected by the presence of these compounds. In addition, this structure tends to accumulate a greater amount of metabolites since it is in direct contact with the extract.

The increase in the concentration of the extracts caused a decrease in the growth of the plants, having the highest concentrations, the shortest lengths of seedlings, or causing their death, as observed in the tomato in the extract at a 
concentration of $20 \%$. Results such as those found by Capobiango et al. (2009) demonstrate that in certain concentrations, such as $10 \%$ aqueous extract of Joanesia princeps leaves, the length of the roots decreased and in the $50 \%$ extract, growth does not occur. The authors also evaluated the aqueous extract of the leaves of Casearia sylvestris and observed that an increase in the concentration of the extracts led to less root growth.

Oliveira et al. (2013) found the same results with aqueous and ethanolic extracts of Vochysia divergens, demonstrating that at a concentration of $2.5 \%$ there was a significant reduction in the length of roots and stems of lettuce and tomato seedlings. This demonstrates that, depending on the species tested, the concentration of the extract from which a negative change in growth occurs is variable. These data corroborate the results found by this work, in which the extracts of $N$. guianensis caused reductions in seedling growth.

\section{Conclusions}

In laboratory and greenhouse conditions, extracts and dry powder added to vermiculite have allelochemical action, negatively interfering with the germination, especially of tomato seeds, and initial seedling growth of lettuce and tomato. These results demonstrate that the tested hypothesis is valid and that Norantea guianensis can negatively influence the development and survival of other plant species used in floristic compositions.

\section{Acknowledgments}

The authors are grateful to the National Council for Scientific and Technological Development (CNPq) for providing the Scientific Start-up Grant (PIBIC) and the present research grant (PQ2 and PQ1d) and to the Coordination for the Improvement of Higher Education Personnel (Capes) for the master and doctoral level scholarships. We would also like to thank the Pantanal Research Centre (CPP), National Institute of Science and Technology in the Wetlands (INAU), National Council for Scientific and Technological Development $(\mathrm{CNPq} / \mathrm{MCT})$, Foundation to Support the Development of Education, Science and Technology of the State of Mato Grosso do Sul (FUNDECT) and the University Anhanguera-Uniderp for funding the GIP project.

\section{References}

Abenalovi M, Cacco G, Sorgoná A, Marabottini R, Paolacci A, Ciaffi M \& Badiami M. 2006. The inihibitory effects of coumarin on the germination of Durum wheat (Triticum turgidum ssp., cv. Simeto) seeds. Journal of Chemical Ecology 32: 489-506. https://doi.org/10.1007/s10886-005-9011-x

Almeida GD, Zucoloto M, Zetun MC, Coelho I \& Sobreir FM. 2008. Estresse oxidativo em células vegetais mediante aleloquímicos. Revista Facultad Nacional de Agronomía 61: 4237-4247.

Alves CCF, Alves JM, Silva TMS, Carvalho MG \& Jacob Neto J. 2003. Atividade alelopática de alcalóides glicosilados de Solanum crinitum Lam. Floresta e Ambiente 10(1): 93-97.

Angelo PM \& Jorge N. 2007. Compostos fenólicos em alimentos - uma breve revisão. Instituto Adolfo Lutz, 66(1): 1-9.

Ayers R \& Westcot DW. 1991. A qualidade da água na agricultura. Estudos FAO. Irrigação e drenagem, 29 revisado 1. Campina Grande, BR: UFPb.

Capobiango RA, Vestena S \& Bittencourt HC. 2009. Alelopatia de Joanesia princeps Vell. e Casearia sylvestris Sw. sobre espécies cultivadas. Revista Brasileira de Farmacognosia 19: 924-930. https:// doi.org/10.1590/S0102-695X2009000600023

Cardoso JC. 2013. Melhoramento de espécies ornamentais como estratégia para o desenvolvimento e autossuficiência do setor. Horticultura Brasileira 31:171-171. https://doi.org/10.1590/S0102-0536201 3000100028

Carmo FMS, Poeiras LM, Gonçalves AB, Mello SM, Meira-Neto JAA, Lima e Borges EE \& Silva AF. 2012. Germinação do banco de sementes de espécies nativas sob dossel de espécies exóticas. Revista Árvore 36: 583-591. https://doi.org/10.1590/ S0100-67622012000400001

Cipollini D, Stevenson R, Enright S, Eyles A \& Bonello P. 2008. Phenolic metabolites in leaves of the invasive shrub, Lonicera maackii, and their potential phytotoxic and anti-herbivore effects. Journal of Chemical Ecology 34: 144-152. https://doi.org/10.1007/s108 86-008-9426-2

Coelho MFB, Maia SSS, Oliveira AK \& Diógenes FEP. 2011. Atividade alelopática de extrato de sementes de juazeiro. Horticultura Brasileira 29: 108-111. http://dx.doi.org/10.1590/S0102-053620110001000 $\underline{18}$

Cunha CN, Arruda EC, Pinto JRR, Gurani Neto G, Oliveira MG \& Costa CP. 2008. Avaliação ecológica rápida - vegetação e flora - Parque Nacional de Chapada dos Guimarães (Chapada dos Guimarães, MT) Cuiabá. (Relatório Técnico).

Dressler S. Marcgraviaceae. 2004. In The families and genera of vascular plants (Kubitzki K, ed.). Flowering plants. Vol. 6. Dicotyledons. Celastrales, Oxalidales, Rosales, Cornales, Ericales. Germany: Springer. pp. 258-265. http://dx.doi.org/10.1007/978- 


\section{$\underline{3-662-07257-8}$}

Ferreira AG. Interferência: competição e alelopatia. 2004. In Germinação: do básico ao aplicado (Ferreira AG \& Borghetti F, eds.). Porto Alegre: Artmed. pp. 251-262.

Ferreira AG \& Aquila MEA. 2000. Alelopatia: Uma área emergente da ecofisiologia. Revista Brasileira de Fisiologia Vegetal 12: 175- 204.

Fontoura FM, Matias R, Ludwig J, Oliveira AKM, Bono JAM, Martins PFRB ... \& Guedes NMR. 2015. Seasonal effects and antifungal activity from bark chemical constituents of Sterculia apetala (Malvaceae) at Pantanal of Miranda, Mato Grosso do Sul, Brazil. Acta Amazonica 45: 283-292. https://doi.org/10. 1590/1809-4392201500011

Fujii Y \& Hiradate S. 2007. Allelopathy: new concepts \& methodology. Enfield: Science Publishers.

Gatti AB, Perez SCJG \& Lima MIS. 2004. Efeito alelopático de Aristolochia esperanzae O. Kuntze na germinação e no crescimento de Lactuca sativa L. e Raphanus sativus L. Acta Botanica Brasilica 18: 459472. https://doi.org/10.1590/S0102-3306200400030 $\underline{0006}$

Gonzalez V, Weston LA \& Cheniae GM. 1998. Inhibition of photosystem II electron transfer reaction by sorgoleone, a natural product. Journal of Agricultural and Food Chemistry 45: 1415-1421.

Hagemann TR, Benin G, Lemes C, Marchese JA, Martin TN, Pagliosa ES \& Beche E. 2010. Potencial alelopático de extratos aquosos foliares de aveia sobre azevém e amendoin-bravo. Bragantia 69: 509-518. https://doi.org/10.1590/S0006-87052010000300001

Heiden G, Barbieri RL \& Stumpf ERT. 2006. Considerações sobre o uso de plantas ornamentais nativas. Revista Brasileira de Horticultura Ornamental 12: 27. https://doi.org/10.14295/rbho.v12i1.60

Labouriau LG \& Agudo M. 1987. On the physiology of seed germination in Salvia hispanica L. I - Temperature effects. Anais da Academia Brasileira de Ciências 59: 37-50.

Luz SM, Souza Filho APS, Guilohn GMSP \& Vilhena KSS. 2010. Atividade alelopática de substâncias químicas isoladas da Acacia mangium e suas variações em função do $\mathrm{pH}$. Planta Daninha 28: 479487. https://doi.org/10.1590/S0100-8358201000030 $\underline{0004}$

Macias FA, Galindo JCG, Molinillo JMG \& Cutler HG. 2003. Allelopathy: chemistry and mode of action of allelochemicals. Boca Raton: CRC Press.

Macias FA, Simonet AN \& Galindo JCG. 1997. Bioactive steroids and triterpenes from Melilotus messanensis and their allelopathic potential. Journal of Chemical Ecology 23:1781-1803.

Magiero EC, Assmann JM, Marchese JA, Capelin D, Paladini MV \& Trezzi MM. 2009. Efeito alelopático de Artemisia annua L. na germinação e desenvolvimento inicial de plântulas de alface (Lactuca sativa L.) e leiteiro (Euphorbia heterophylla L.). Revista Brasileira de Plantas Medicinais 11: 317-324. https:// doi.org/10.1590/S1516-05722009000300014

Maguire JD. 1962. Speed of germination aid in selection and evaluation for seedling and vigour. Crop Sci- ence 2: 176-177.

Maraschin-Silva F \& Áquila MEA. 2006. Contribuição ao estudo do potencial alelopático de espécies nativas. Revista Árvore 30: 547-555. https://doi.org/10.1590/ S0100-67622006000400007

Matos JFA. 2009. Introdução a fitoquímica experimental. 3ed. Fortaleza: UFC.

Mulac D \& Humpf HU. 2011. Cytotoxicity and accumulation of ergot alkaloids in human primary cells. Toxicology 282: 112-121. https://doi.org/10.1016/j.tox. $\underline{2011.01 .019}$

Murakami C, Cardoso FL \& Mayworm MAS. 2009. Potencial fitotóxico de extratos foliares de Aloe arborescens Miller (Asphodelaceae) produzidos em diferentes épocas do ano. Acta Botanica Brasilica 239: 111-117. https://doi.org/10.1590/S0102-3306200900 $\underline{0100014}$

Nazemi AH, Asadi GA \& Ghorbani R. 2018. Allelopathic potential of lavander's extract and coumarin applied as pre-plant incorporated into soil unde agronomic conditions. Planta Daninha 36: e018160777. https:// doi.org/10.1590/s0100-83582018360100069

Oliveira AKM, Matias R, Lopes SS \& Fontoura FM. 2014. Allelopathy and influence of leaves of Palicourea rigida (Rubiaceae) on seed germination and seedling formation in lettuce. Bioscience Journal 30 : 938-947.

Oliveira AKM, Ribeiro JWF, Fontoura FM \& Matias R. 2013. Leaf extract effects of Vochysia divergens on lettuce and tomato. Allelopathy Journal 31: 129-138.

Oliveira AKM, Ribeiro JWF, Matias R, Gusmão D \& Pereira KCL. 2011. Potencial alelopático de folhas frescas de bacupari (Rheedia brasiliensis (Mart.) Planch. \& Triana) na germinação de alface. Revista Brasileira de Biociências 9: 550-553.

Pattnaik SK \& Misra MK. 1987. Morphology and germination characteristics of Aristida setacea seeds. Acta Botanica Hungarica 33: 413-420.

Peixoto Sobrinho TJSP, Silva CHTP, Nascimento JE, Monteiro JM, Albuquerque UP \& Amorim ELC. 2008. Validação de metodologia espectrofotométrica para quantificação dos flavonóides de Bauhinia cheilantha (Bongard) Steudel. Revista Brasileira de Ciências Farmacêuticas 44: 683-689. https://doi.org/10. 1590/S1516-93322008000400015

Pereira KCL, Oliveira AKM, Matias R, Rizzi ES \& Rosa AC. 2018. Potencial alelopático do extrato etanólico de Anacardium humile A.St.-Hil. (cajuzinho-do-cerrado) na germinação e formação de plântulas de Lactuca sativa L. (alface), Lycopersicon esculentum Mill. (tomate) e Senna obtusifolia (L.) Irwin \& Barneby (fedegoso). Gaia Scientia 12: 144-160. https://doi.org/10.22478/ufpb.1981-1268.2018v12n 2.37091

Piettá PG \& Simonetti P. 1999. Antioxidant food supplements in human health. San Diego: Academic Press.

Rice EL. 1984. Allelopathy. 2ed. New York: Academic Press.

Rizzi ES, Pereira KCL, Abreu CAA, Silva BCFL, Fernandes RM, Oliveira AKM \& Matias R. 2016. Allelopathic potential and phytochemistry of cambarazinho (Vochysia haenkeana (Spreng.) Mart.) 
leaves in the germination and development of lettuce and tomato. Bioscience Journal 32: 98-107. https://doi.org/10.14393/BJ-V32N1A2016-29614

Rodrigues IMC, Souza Filho APS, Ferreira FA \& Demuner AJ. 2010. Prospecção química de compostos produzidos por Senna alata com atividade alelopática. Planta Daninha 28: 1-12. https://doi.org/10. 1590/S0100-83582010000100001

Saleh NAM \& Towers GHN. 1974. Flavonol glycosides of Norantea guianensis flowers. Phytochemistry 13: 2012.

Simões CMO, Schenkel EP, Mello JCP, Mentz LA \& Petrovick PR. 2017. Farmacognosia: do produto natural ao medicamento. Porto Alegre/Florianópolis: Artmed Editora.

Silva EAS, Lobo LT, Silva GA, Souza Filho APS, Silva MN, Arruda AC ... \& Arruda MASP. 2013. Flavonoids from leaves of Derris urucu: assessment of potential effects on seed germination and development of weeds. Anais da Academia Brasileira de Ciências 85: 881-889. https://doi.org/10.1590/S0001-376520 13000300004

Sousa CMM, Silva HR, Vieira Jr GM, Ayres MCC, Costa CLS, Araújo DS ... \& Chaves MH. 2007. Fenóis totais e atividade antioxidante de cinco plantas medicinais. Química Nova 30: 351-355. https://doi.org/10. 1590/S0100-40422007000200021

Souza Filho APS, Guilhon GMSP \& Santos LS. 2010. Methodologies applied in allelopathic activity evaluation studies in the laboratory: a critical review. Planta Daninha 28: 689-697. https://doi.org/10.1590/ S0100-83582010000300026

Willis RJ. 2007. The history of allelopathy. Dordrecht: Springer. https://doi.org/10.1007/978-1-4020-4093-1 